\title{
Management and Arrangement Model of Loloan River Area for Conservation and Development as a Tourist Attraction Area
}

\author{
I Gusti Agung Putu Eryani ${ }^{1 *}$, Cok Agung Yujana ${ }^{1}$, I Wayan Wesna Astara ${ }^{2}$ \\ ${ }^{1}$ Faculty of Engineering and Planning, Warmadewa University, Denpasar, 80239, \\ Indonesia \\ ${ }^{2}$ Faculty of Law, Warmadewa University, Denpasar, 80239, Indonesia \\ eryaniagung@gmail.com
}

Received 26-08-2020; accepted 07-09-2020

\begin{abstract}
Among the massive areas in the city of Denpasar that have changed land functions, there are still some areas that are still preserved with their natural landscapes. One of them is the Loloan River area. This area is currently planned to be developed as an area of natural tourist attraction in urban areas. This research aims to make a management and arrangement model of the Loloan River area optimize the development of Renon village around the Loloan River area as a tourist attraction area without lay aside the sustainability of the surrounding environment. The research method used in this study uses descriptive qualitative research methods to create a management and arrangement model that is appropriate to the research location. The result of management and arrangement model of the Loloan River area that can be done in several ways, including empowering the society in efforts to clean up sediment in the Loloan River Basin so that the river's capacity can be optimal, educating the society about the importance of conserving irrigation channels for sustainable water potential and arrangements in the Loloan River area which can be done by planting around the Loloan River area.
\end{abstract}

Keywords: water potential, management, conservation.

\section{Introduction}

The river as a water resource has benefits and an important role in human life. Nowadays, rivers flowing in densely populated residential areas show a tendency to worsen from year to year. Increasing economic development activities, land-use change, and increasing population growth have resulted in high pressure from river areas to the environment [1].

Bali Province, which is a tourism destination, requires a lot of supporting facilities to complement tourism supporting facilities and infrastructure, such as hotels, restaurants, villas, and increased housing development. Currently, the land around the river area in Bali Province has changed its function, especially agricultural lands in urban areas that have been converted into buildings that support tourism

Cite this as: Eryani, I.G.A.P., Yujana, C.A., \& Astara, I.W.W.A. (2020). Management and Arrangement Model of Loloan River Area for Conservation and Development as a Tourist Attraction Area. Civil and Environmental Science Journal (Civense), 3(2), 102-109. doi: https://doi.org/10.21776/ub.civense.2020.00302.5 
activities. As the capital city of Bali Province, Denpasar City is one of the cities in Bali that is experiencing a rapid land conversion [2]. According to land use, most of the land area in Denpasar City is used for non-agricultural lands such as roads, settlements, offices, and others. The area of irrigated rice fields decreased from year to year from 2013 to 2017. From 2016 - 2017, irrigated rice fields decreased by 35 hectares. The conversion of agricultural land, both paddy fields, and non-rice fields is used for non-agricultural lands such as yards, settlements, roads, and others [3]. Land use changed to have an impact on the amount of erosion in the upstream to downstream areas of the river and the discharge of residential waste into the river that resulting in river pollution. This can lead to silting of water bodies, drought in the dry season, and flooding in the rainy season [4].

Among the massive areas in the city of Denpasar that have changed land functions, there are still some areas that are still preserved with their natural landscapes. One of them is the Loloan River area around the traditional village of Renon. This area is currently planned to be developed as an area of natural tourist attraction in urban areas. However, the current condition is not yet supportive to become a tourist area due to the inadequate management and arrangement of the Loloan River area. If it is not managed and arranged properly, its development as a tourist attraction area can cause problems such as land conversion, pollution and so on. Therefore, a management and arrangement model of Loloan River area is needed to optimize the development of Renon village around the Loloan River area as a tourist attraction area without lay aside the sustainability of the surrounding environment.

\section{Material and Methods}

\subsection{Research Location}

This research took place in the Loloan river area (Figure 1), around the Renon Village. This location was taken because this area is under development as a tourist attraction area for Renon Village.

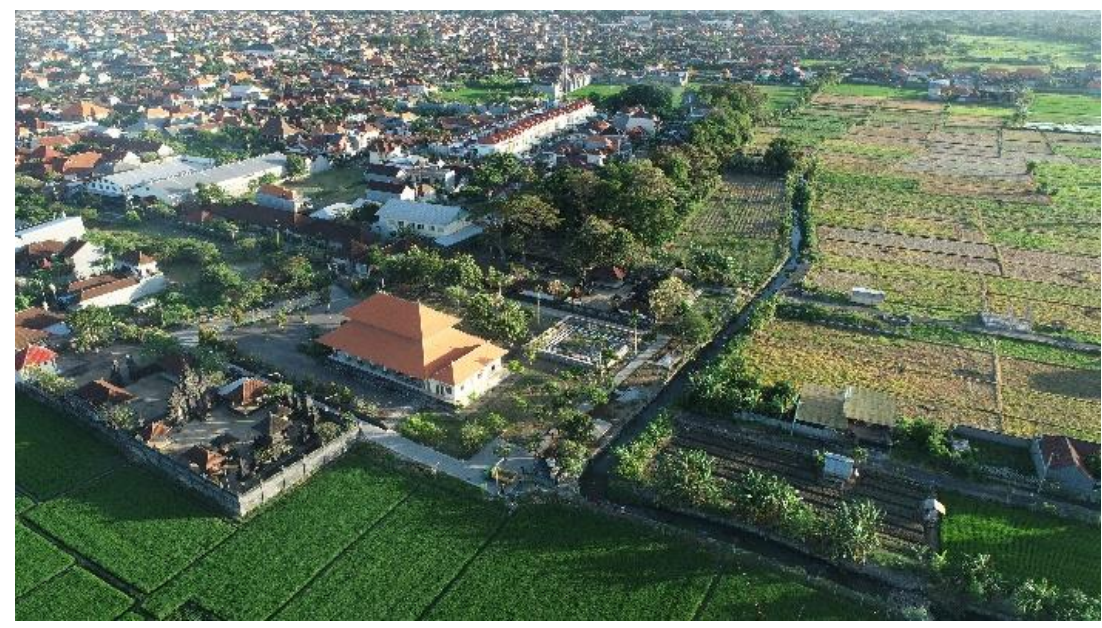

Figure 1. Research Location

\subsection{Research Tools and Materials}

The research tools used in this study were a camera, interview sheets, and a laptop. Besides, it is supported by the Google Earth Pro, drones, and Microsoft Office. Google Earth Pro is used to obtain imagery at the study site for 2015-2019, then drones are used to take existing aerial images. After that, the data obtained were processed using Microsoft Office. The types of data used in this study are primary data and secondary data. Primary data is in the form of data collection obtained through observation, interviews, and focus group discussions (FGD). Secondary data is data obtained from the literature study method from books, journals, magazines, and the internet regarding the research location. The collected data will be used for research and useful for making management and arrangement model of the Loloan River area in Denpasar City. 


\subsection{Data Analysis Technique}

The research method used descriptive qualitative research methods to create a management and structuring model that is appropriate to the research location. This study begins by analyzing the potential that can be developed as a tourist attraction and problems in the research location through direct observation and interviews, after knowing the potential and problems that occur, a management and arrangement model of the Loloan River area is made as an effort to conserve and develop the Loloan River area as an area of tourist attraction. With the management and arrangement model of the Loloan River area, it is hoped that it can optimize the development of Renon Village around the Loloan River area as a tourist attraction area.

\section{Result and Discussion}

\subsection{Loloan River Area}

Loloan River is one of the watersheds that flow in the Denpasar city with a river length of $3.75 \mathrm{~km}$ and irrigates 103 hectares of rice fields [3]. Characteristics of the Loloan River have a very flat riverbed slope ( 0.0032 in the upstream, 0.0032 in the midstream and 0.0025 in the downstream), a narrow river width (average $4.4 \mathrm{~m}$ in the upstream, $4.5 \mathrm{~m}$ in the midstream part and $9 \mathrm{~m}$ downstream) [5]. This situation causes a slow sediment rate that allows flooding if the sediment in the water body is not managed properly [6] [7] [8]. Coupled with changes in the function of land in the area around the river so that the management and arrangement of the river are needed to conserve the sustainability of the water potential of the area.

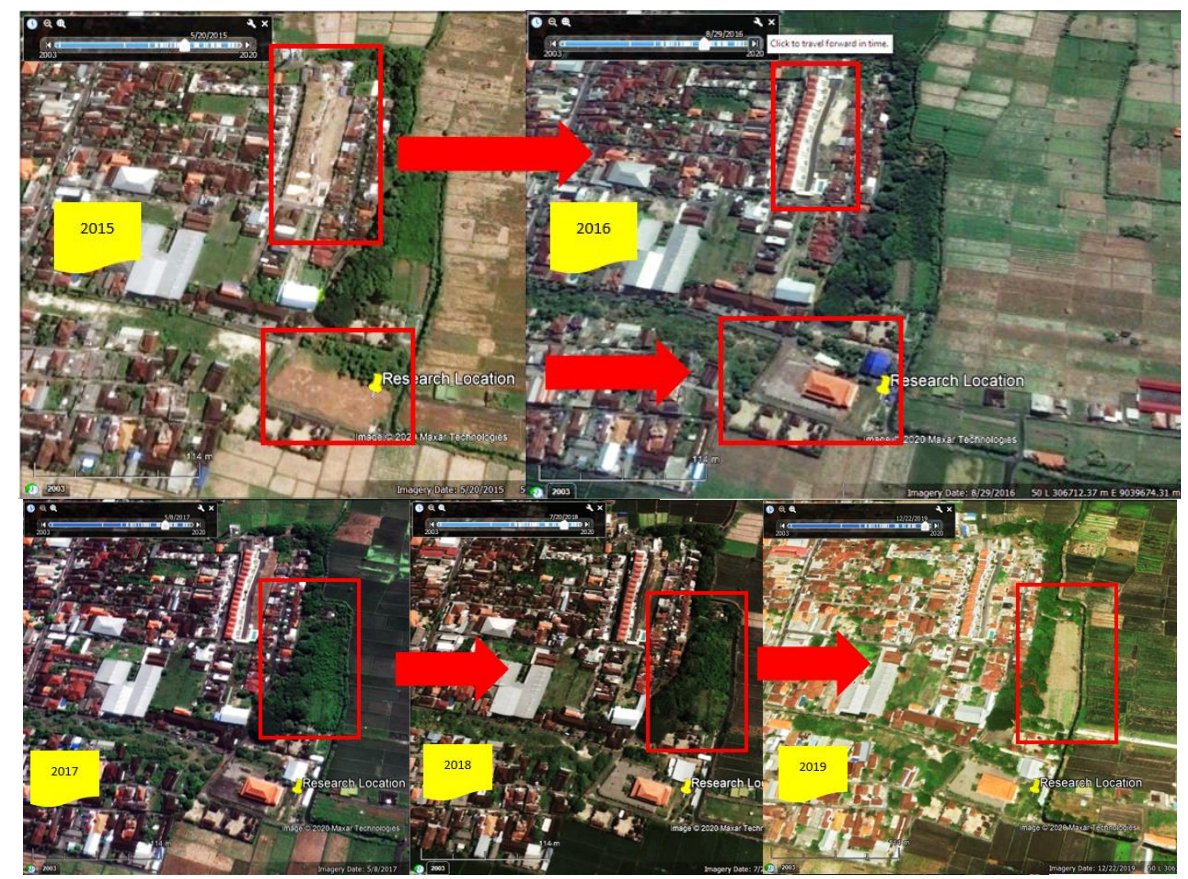

Figure 2. Land Conversion in Loloan River Area

Based on aerial images from Google Earth for 2015-2019 (Figure 2), from 2015 to 2016 there was a land-use change in the area around the study site into built-up land, while from 2017 to 2018 there was no significant change, and in 2019 there was a reduction in green land around research sites. If this area is not managed and arranged properly, this will have an impact on the potential for increased flow coefficient which can increase the potential for flooding during the rainy season and the potential for drought in the dry season. 


\subsection{Tourism Potential of the Loloan River Area}

According to the Big Indonesian Dictionary (KBBI), the potential is the ability, strength, and power that can be developed. Tourism potential is everything that is found in a tourist destination and is an attraction for people to come to visit these places [9]. Based on Law no. 10 of 2009, the notion of tourist attraction is anything that has uniqueness, beauty, and value in the form of a diversity of natural, cultural, and man-made wealth that is the target or purpose of tourist visits [10]. According to the Tourism Law, tourist attraction is one of the efforts in tourism. Tourism business which includes:

- Tourist area

- Transportation services and travel services

- Food and beverage services

- Providing accommodation for entertainment and recreation activities

- Organizing meetings, intensity trips, conferences and exhibitions

- Tourism information services, tourism consulting and guide

- Water and spa tours

Broadly speaking, the tourist attraction is classified into three classifications [11].

- Natural tourist attraction

Sourced from existing natural conditions such as beach tourism, marine, mountainous nature, remote wild areas, parks, and conservation areas.

- Cultural appeal

Having objects that come from the socio-cultural conditions of the community or legacy such as conditions of community customs, social conditions of the community, and traditional events.

- Man-made attraction

Attractiveness that develops something that is human-made or is included as a special attraction, such as folk amusement parks, music festivals, annual festivals, or competition locations (boats, motor cross, etc.). Loloan River is one of the locations that has tourism potential in the form of nature tourism. Around the river area, there is a stretch of rice fields that are still natural, the flow of water from the Loloan River and the existence of the Renon traditional village office area whose area has been paved so that it can be used as a jogging track area or other relaxing recreation.

The location is also easy to reach and has adequate road facilities so that it is not difficult for tourists who want to have a recreation there. The existence of the Loloan River also adds to the attraction of this place to be used as a tourist area. In general, city people are rarely able to see natural conditions due to dense settlements, but this location can be used to be able to carry out natural recreation to relieve the fatigue of urban society as shown in the Figure 3.
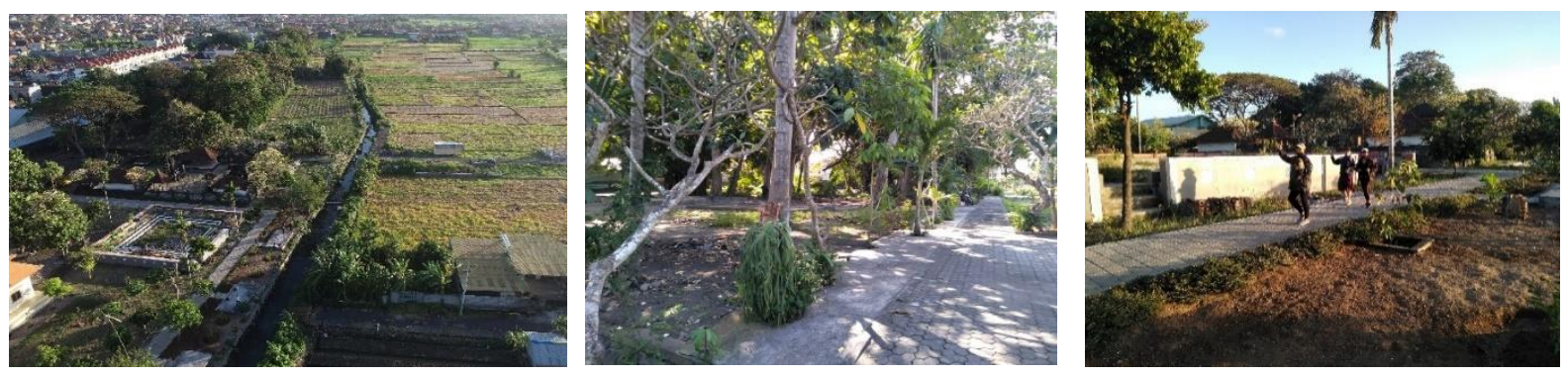

Figure 3. Potential Tourism Attractions of the Loloan River Area

\subsection{Loloan River Area Problems}

The Loloan River is located in the village of Renon which borders the Sanur area which has the potential to become a tourist attraction area. However, the current condition is not yet favorable to be used as a tourist area due to the inadequate management of water potential and the arrangement of the Loloan River area. Several problems still occur in the Loloan River area, including: 
- The existing condition of the irrigation technical channel is still experiencing several problems, such as: in some locations, there are technical channels that are damaged and cause loss of potential water in the channel, there are weeds that grow in water bodies so that the river reservoir does not function as planned as shown in the Figure 4.

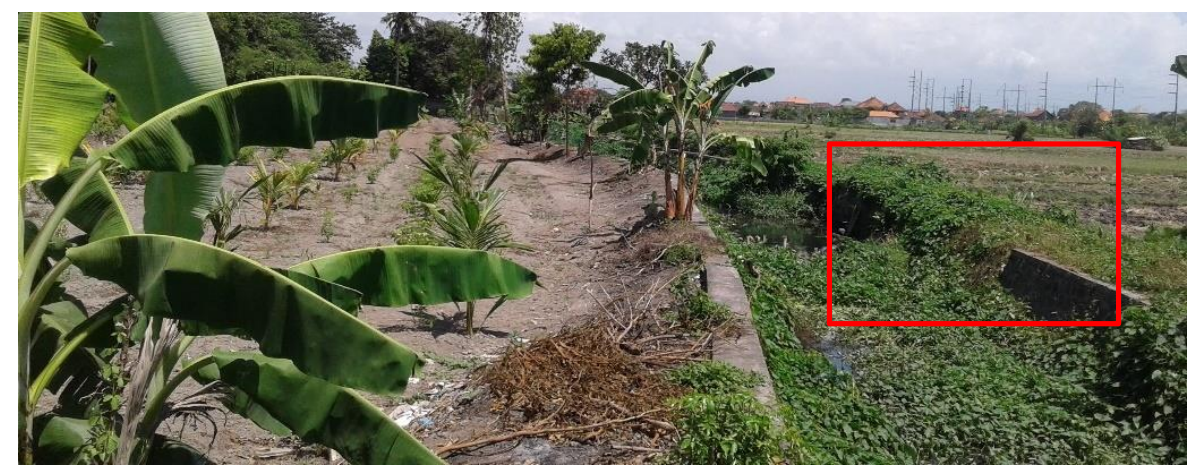

Figure 4. Damage in River Revetment and River Silting

- Lack of society awareness of the importance of conserving the Loloan River which can cause various problems as shown in the Figure 5.

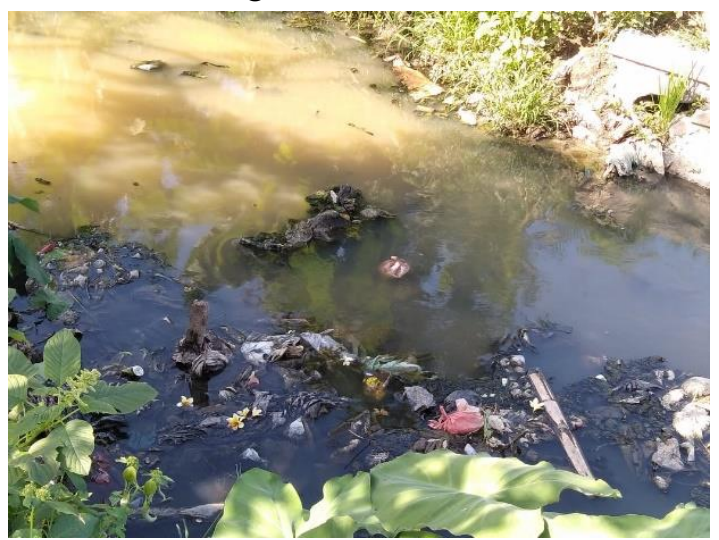

Figure 5. Pollution in Rivers due to Lack of Society Awareness

- The arrangement and conservation around the Loloan River area are still not optimal as shown in the Figure 6.

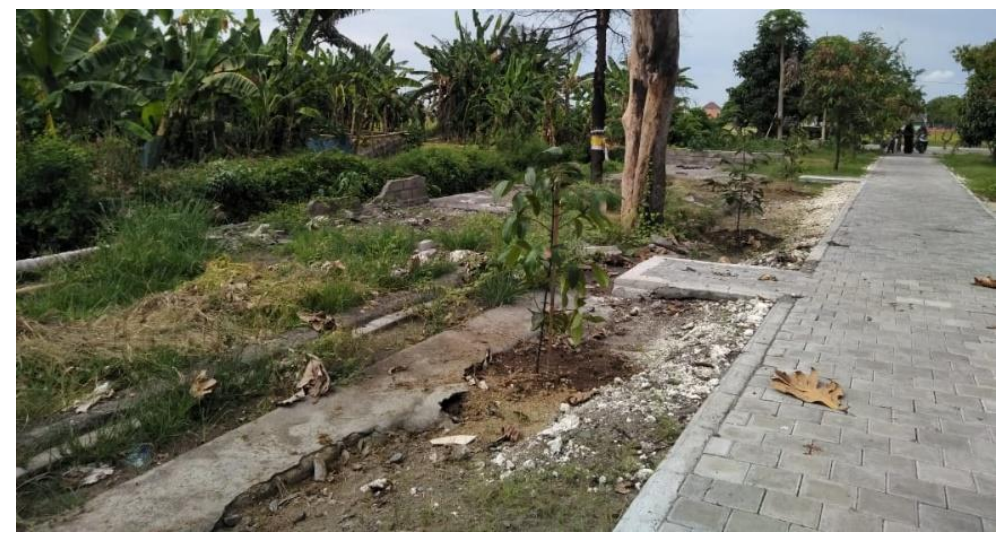

Figure 6. Environmental Conditions around the Loloan River 


\subsection{Management and Arrangement Model of Loloan River Area}

According to Kotler [12], SWOT analysis (strength, weakness, opportunity, threat) is an overall evaluation of strengths, weaknesses, opportunities, and threats. the benefit of a SWOT analysis is to increase the knowledge and understanding of the organization so that it can analyze what are the strengths, weaknesses, opportunities, and threats in the organization to get the right strategy by using existing strengths and opportunities to overcome all threats and reduce existing weaknesses so that the organization can survive and be able to thrive.

According to Riadi [13], SWOT analysis has a function to obtain information from situation analysis and separate it into internal issues (strengths and weaknesses) and external issues (opportunities and threats).

From the existing problems and potentials, a SWOT model for the management and arrangement of the Loloan River area is made as follows.

Table 1. SWOT Model for the Management and Arrangement of the Loloan River Area

\begin{tabular}{|c|c|c|c|}
\hline Strength (S) & Weakness (W) & Opportunity (O) & Threat (T) \\
\hline $\begin{array}{l}\text { - Has a potential } \\
\text { tourist attraction }\end{array}$ & $\begin{array}{l}\text { There is still a } \\
\text { problem of } \\
\text { pollution due to } \\
\text { garbage in the } \\
\text { Loloan River }\end{array}$ & $\begin{array}{l}\text { - Can be developed as a } \\
\text { tourist attraction }\end{array}$ & $\begin{array}{l}\text { - River pollution which if } \\
\text { not managed can } \\
\text { damage the } \\
\text { environment of the } \\
\text { Loloan River }\end{array}$ \\
\hline $\begin{array}{l}\text { - Easy to reach, close } \\
\text { to the city center }\end{array}$ & $\begin{array}{l}\text { Lack of } \\
\text { arrangement of the } \\
\text { area around the } \\
\text { Loloan river and } \\
\text { damaged river } \\
\text { embankments }\end{array}$ & $\begin{array}{l}\text { The strategic location } \\
\text { with the trajectory of } \\
\text { the tour makes it easy to } \\
\text { promote the area as a } \\
\text { tourist attraction }\end{array}$ & $\begin{array}{l}\text { There is a possibility of } \\
\text { flooding due to silting } \\
\text { thus reducing the } \\
\text { potential for existing } \\
\text { tourist attractions }\end{array}$ \\
\hline $\begin{array}{l}\text { - The environment is } \\
\text { still natural and } \\
\text { there have not been } \\
\text { many changes in } \\
\text { land use }\end{array}$ & $\begin{array}{l}\text { There is still a lack } \\
\text { of awareness and } \\
\text { education of the } \\
\text { surrounding society } \\
\text { about the } \\
\text { conservation of the } \\
\text { area around the } \\
\text { Loloan River }\end{array}$ & $\begin{array}{l}\text { Its location in the urban } \\
\text { area is perfect for city } \\
\text { people who are tired of } \\
\text { routines and want } \\
\text { simple tours that are } \\
\text { easy to reach }\end{array}$ & $\begin{array}{l}\text { - Starting from changes } \\
\text { in land use, namely } \\
\text { changes in paddy fields } \\
\text { into settlements }\end{array}$ \\
\hline $\begin{array}{l}\text { - The role of } \\
\text { traditional villages } \\
\text { and communities } \\
\text { that are active in its } \\
\text { development }\end{array}$ & $\begin{array}{l}\text { There is still a lack } \\
\text { of promotion by } \\
\text { traditional village } \\
\text { administrators } \\
\text { regarding the } \\
\text { potential for tourist } \\
\text { attractions around } \\
\text { the Loloan river } \\
\text { area }\end{array}$ & $\begin{array}{l}\text { - It is easy to promote } \\
\text { because it already has a } \\
\text { unique characteristic, } \\
\text { namely the Baris Cina } \\
\text { Dance, so that it can be } \\
\text { developed with various } \\
\text { tourist facilities, such as } \\
\text { museums or cultural } \\
\text { exhibitions. }\end{array}$ & $\begin{array}{l}\text { There is an internal } \\
\text { conflict from the } \\
\text { indigenous village } \\
\text { community if it has } \\
\text { been developed as a } \\
\text { tourist attraction area } \\
\text { related to the impact of } \\
\text { tourism facilities that } \\
\text { support the } \\
\text { development of the area }\end{array}$ \\
\hline
\end{tabular}

Based on Table 1, several management strategies and arrangements of the Loloan River area can be formulated as follows. 
- Empowerment of the surrounding society and related stakeholders in the form of cooperation in efforts to clean the sedimentation in the Loloan River area so that the river's capacity can be optimal. This strategy can be carried out by holding cooperation to clean the water body of the Loloan River by involving the participation of the society and related stakeholders to clean the Loloan River, whose existing conditions are still overgrown with weeds and plants and installing garbage catcher nets to prevent silting due to waste in water bodies.

- Educate about the importance of conserving irrigation channels so that the water potential of the Loloan River can be used optimally. With this education, it is hoped that the surrounding society will understand the importance of conserving the Loloan River area to reduce the negative impacts that can occur due to changes in land use and the habits of the surrounding society which can cause pollution and damage to the Loloan River area.

- Planning for arrangement and conservation of the Loloan River area. This can be done by planting appropriate crops according to climatic conditions and the needs of the surrounding society, as well as repairing river embankments to reduce water loss in water bodies that cause drought and sedimentation of water bodies.

- Promoting the tourist attraction of the Loloan River area to increase the interest of the surrounding society to visit the area, so that it can be developed as a tourist attraction area that might improve the economic level of the surrounding area.

- Make strict rules regarding the behavior of the surrounding society for not to pollute the Loloan River, and make a river care community to increase society awareness of the importance of conserving the Loloan River area.

Based on this model, it can be seen that the Loloan River area has the potential to be developed as a tourist attraction area, its location in the city center makes this location easy to reach, and the natural scenery of rice fields and rivers around the location. This area also can be used as a simple recreation area for the surrounding society who want to eliminate boredom due to work and the stress of life in the city. But before this location is further developed as a tourist attraction area, there is a need for management in the Loloan River area, especially regarding the problem of waste pollution and damage to river embankments. After the management is carried out, support is needed from the side of the arrangement of the area, so that this area becomes sustainable, planting plants around the Loloan River is very necessary, and it is not impossible to add lighting if it is open for the night.

\section{Conclusions}

Based on the explanation above, it can be concluded that several things are as follows.

1. The Loloan River is one of the rivers that flow in Denpasar City. The Loloan River located in Renon Village has a tourist attraction as a natural tourism attraction. The view of the rice fields that are still maintained, the flow of water from the Loloan River, and the paved location provide facilities for the surrounding society to do jogging and nature recreation in urban areas. However, the current condition is not yet favorable to be used as a tourist area due to the inadequate management and the arrangement of the Loloan River area.

2. To optimize the development of the Loloan river area as an area of tourist attraction, it can be done by empowering the surrounding society in the form of cooperation in efforts to clean up weeds in the Loloan river basin so that the river's capacity can be optimal, socializing the importance of conserving irrigation channels for potential Loloan River water can be used optimally as well as planning the arrangement and conservation of the Loloan River watershed. This can be done by planting appropriate crops according to climatic conditions and the needs of the surrounding society, as well as repairing river embankments to reduce water loss in water bodies that cause drought and sedimentation of water bodies. 


\section{Acknowledgments}

Acknowledgments submitted to the Warmadewa University and community of the traditional village of Renon who have supported the completion of this paper.

\section{References}

[1] D. Widodo, B. Lupiyanto, R., dan Wijaya, "Pengelolaan Kawasan Sungai Code Berbasis Masyarakat," J. Sains dan Teknol. Lingkung., vol. 2, no. 1, 2010.

[2] G. P. D. S. Pratiwi and I. P. A. Citra, "Dinamika dan Kesesuaian Arahan Fungsi Kawasan Di Kota Denpasar," J. Pendidik. Geogr. Undiksha, vol. 7, no. 1, 2019, doi: 10.23887/jjpg.v7i1.20674.

[3] Pemerintah Kota Denpasar, "Rencana Kerja Pemerintah Daerah Semesta Berencana 2020," Denpasar, $2020 . \quad$ [Online]. Available: https://bappeda.denpasarkota.go.id/new/public/ckfinder/userfiles/files/RKPD 2020.pdf.

[4] I. G. A. P. Eryani, "Potensi Air dan Metode Pengelolaan Sumber Daya Air di Daerah Aliran Sungai Sowan Perancak Kabupaten Jembrana," Paduraksa, vol. 3, no. 1, pp. 32-41, 2014.

[5] CV. Permata Denpasar, "Review Masterplan Drainase Kota Denpasar," Denpasar, 2016. [Online]. Available: http://sippa.ciptakarya.pu.go.id/sippa online/ws file/dokumen usulan/drainase/DRAINASE 51-71-2016.pdf.

[6] S. A. Nelson, "River Systems \& Causes of Flooding," Tulane University, 2016. https://www.tulane.edu/ sanelson/Natural_Disasters/riversystems.htm.

[7] D. Indriastuti, "Analysis of Runoff Due To the Change in Land Use At the Watershed of Upstream Ciliwung," J. Civ. Eng. Forum, vol. 2, no. 1, p. 131, 2016, DOI: 10.22146/jcef.26576.

[8] DELWP, Guidelines for Development in Flood Affected Areas, no. February. 2019.

[9] O. A. Yoeti, Pengantar Ilmu Pariwisata. Bandung: Angkasa, 1996.

[10] Kementerian Pariwisata Republik Indonesia, Undang-Undang Republik Indonesia Nomor 10 Tahun 2009. Indonesia, 2009.

[11] H. Marpaung and H. Bahar, Pengantar Pariwisata. Bandung: Alfabeta, 2002.

[12] P. Kotler, Marketing Management. Jakarta: Prenhallindo, 2000.

[13] M. Riadi, "Strength Weakness Opportunities Threats (SWOT)," kajianpustaka.com, 2013. http://www.kajianpustaka.com (accessed Aug. 04, 2019). 